\title{
The life cycle costing (LCC) approach: a conceptual discussion of its usefulness for environmental decision-making
}

\author{
Pernilla Gluch ${ }^{\mathrm{a}, *}$, Henrikke Baumann ${ }^{\mathrm{b}}$ \\ ${ }^{a}$ Department of Building Economics and Management, Chalmers University of Technology, Göteborg S-412 96, Sweden \\ ${ }^{\mathrm{b}}$ Environmental Systems Analysis, Chalmers University of Technology, Göteborg, Sweden
}

Received 17 April 2000; accepted 16 October 2003

\begin{abstract}
Ten LCC-oriented environmental accounting tools suggested as useful in environmental decision-making have been identified. However, their implementation in the building industry seems to be limited, which opens up for a conceptual discussion. The purpose of this article is to discuss theoretical assumptions and the practical usefulness of the LCC approach in making environmentally responsible investment decisions. LCC's monetary unit and extended scope may speak in favour of using LCC but LCC fails to handle irreversible decisions, neglects items that have no owner and does not consider costs to future generations. Moreover, LCC does not take into account the decision makers' limited ability to make rational decisions under uncertainty. LCC's practical usefulness is constrained by its oversimplification to a monetary unit, the lack of reliable data, complexity of the building process and conceptual confusions. To handle these inconsistencies in future development of environmental decision support tools three research solutions are proposed.
\end{abstract}

(C) 2003 Elsevier Ltd. All rights reserved.

Keywords: Life cycle costing; LCC; Decision support tools; Building; Construction; Investment decisions; Environmental management

\section{Introduction}

Many traditional cost-accounting systems lead to incorrect investment decisions concerning environmental costs [1-5]. One problem is for example that demolition and recycling costs appear outside the boundary of the traditional accounting system. A popular way of solving this problem has been to suggest the use of life cycle costing (LCC) which includes such costs [6-9].

However, this may not be an appropriate solution since LCC was originally not developed in an environmental context. 'Traditional' LCC is a type of investment calculus used to rank different investment alternatives [7,10]. Another objection concerns the system boundaries of LCC. The main difference between traditional investment calculus and LCC is that the LCC approach has an expanded life cycle perspective, and thus considers not only investment costs, but also operating costs during the product's estimated lifetime. However, such an expansion of the system boundaries does not include all environmental costs. It is important to

\footnotetext{
* Corresponding author. Tel.: +46-31-7721961; fax: +46-31-7721964.

E-mail addresses: gluch@bem.chalmers.se (P. Gluch), henrikke.baumann@esa.chalmers.se (H. Baumann).
}

emphasise that a "traditional" LCC does not become an environmental accounting tool just because it contains the words life cycle. This fact may seem trivial, but since LCC is often used in an environmental context it cannot be enough emphasised since ambiguity is one reason why individuals make bad or at least irrational decisions [11,12].

The history of LCC began in the US Department of Defence in the mid-1960s [13]. In the mid-1980s attempts were made to adapt LCC to building investments [14]. Recently several research projects have been carried out aimed at developing the LCC methodology for the construction industry and placing LCC in an environmental context. One example is Abraham and Dickinson's [6] study of the disposal of a building in which LCC calculation is used to quantify disposal costs. Sterner [7] developed a model for the evaluation of tenders, where she uses LCC methodology to calculate the total energy costs for buildings. Aye et al. [8] used LCC to analyse a range of property and construction options for a building. Bogenstätter [9] advocate the usability of performing an LCC calculation in the early design phase. He developed a model using specific characteristic values of LCC, i.e. standardised typological figures. He suggests defined specifications from similar buildings as key solutions to the usability problem. 
Despite an increasing enthusiasm to propose the LCC approach as useful in an environmental context, the adoption and application of LCC in the building sector remains limited [15-17]. Cole and Sterner [18], Flanagan et al. [19] as well as Norman [20] suggest that practitioners' 'imperfect understanding' of LCC's merits is the main cause of the limited adoption of LCC. The authors indicate that there exists a gap between theory and practice. However, neither of them sufficiently explains underlying reasons to this gap. Moreover, the actual incorporation of environmental consequences in the LCC approach is not sufficiently clarified. Furthermore, lack of incentives to use LCC has been pointed out as a reason to why the approach has not been more extensively adopted by practitioners $[18,19]$. In order to investigate whether LCC is as promising as enthusiasts suggest, this article discusses LCC from the perspective of how useful and appropriate the LCC approach is for environmental decision-making in general and for environmental considerations in building investment decisions in particular. The discussion is made from a business perspective, typically when LCC is used in an investment decision context where at least two alternatives are compared.

\section{LCC-oriented environmental accounting tools}

Traditional accounting techniques have been found inadequate for the handling of environmental issues $[1,2]$ and a lack of tools that elevate environmental issues by 'translating' environmental issues into monetary terms is often assigned as the stumbling-block $[7,13,21,22]$. The development of corporate accounting tools that consider environmental issues started in the early 1990s by amongst others Epstein [13], Schaltegger [23], Spitzer and Elwood [24], and Gray et al. [25]. Corporate environmental accounting has been defined as

...the process of identification, measurement, accumulation, analysis, preparation, interpretation and communication of financial (and non-financial) information used by management to plan, evaluate and control the environmental aspects of an organization. [26, p. 155].

'Traditional' LCC is vaguely defined by the building and construction assets standard ISO15686 as: a technique which enables comparative cost assessments to be made over a specified period of time, taking into account all relevant economic factors both in terms of initial costs and future operational costs. Thus, in an ideal case, LCC is used to optimise product performance and lifetime cost of ownership [27]. Through an inventory ten LCC tools have been identified, see Table 1.

Table 1 shows the variants of the LCC tools, with a more or less-stated environmental approach, that have been developed during this last decade. Originating from this tools researchers have developed tools that in turn are adapted and applied for different contexts, such as building investments (for example [6-9]). By adjusting some variables in the equation, the tools become "environmental". The tools have been given different 'names', but are similar in their approach and structure. Words like 'full', 'total', 'true', 'whole' and 'life cycle' indicate that there has been an effort to develop traditional accounting approaches for use as environmental accounting tools.

In common for these modified environmental accounting tools is that they attempt to include environmental impacts as costs into the corporate accounting systems. The environmental accounting tools aim at allocating where a resource is used and to measure it [32,33], in other words, an attempt to detect costs hidden in overhead accounts [34].

\section{Theoretical assumptions in the LCC approach}

The development of LCC and similarly structured tools and methods has its origin in the normative neoclassical economic theory which states that firms seek to maximise profits by always operating with full knowledge [35]. According to the theory, decision makers must have consistent preferences; they also have to know their preferences as well as the available alternatives [36]. Thus, they must have access to information about the consequences of selecting each alternative and be able to combine this information with the expected utility, which in turn discounts or weighs outcomes by the probability of their occurrence. This implies that the behaviour of the 'economic man' in neoclassical economic theory is always rational. However, descriptive decision-making studies [36] have shown that individuals do not make rational decisions, especially when uncertainty is involved because of complex and long-term consequences, which is typical for environmental decisionmaking.

There are four inherent limitations in neoclassical economic theory that restricts its use in an environmental context:

- It cannot handle decision-making under genuine uncertainty since it assumes that the decision-maker is always rational and has access to complete information concerning alternatives and outcomes.

- It assumes that alternatives are always available. With such a view irreversible changes, such as extinction of species, are not considered as a problem since they can be 'replaced' without changing the ecosystem.

- It ignores items that have no owner, such as the natural environment.

- It over-simplifies multi-dimensional environmental problems since it assumes that everything can be expressed as a one-dimensional unit, such as monetary figures. 
Table 1

Corporate environmental accounting tools

\begin{tabular}{|c|c|c|}
\hline Concept & Definitions/description & Cost categories \\
\hline Full cost accounting (FCA) & $\begin{array}{l}\text { Identifies and quantifies the full range of costs } \\
\text { throughout the life cycle of the product, product } \\
\text { line, process, service or activity [28] }\end{array}$ & $\begin{array}{l}\text { Identifies and quantifies (1) direct, (2) indirect } \\
\text { and (3) intangible costs }\end{array}$ \\
\hline Full cost environmental accounting (FCEA) & $\begin{array}{l}\text { Embodies the same concept as FCA but high- } \\
\text { lights the environmental elements }[24]\end{array}$ & Varying \\
\hline Total cost assessment (TCA) (I) & $\begin{array}{l}\text { Long-term, comprehensive financial analysis of } \\
\text { the full range of internal costs and savings of } \\
\text { an investment }[28,29]\end{array}$ & (1) Internal costs and savings \\
\hline Total cost accounting (TCA) (II) & $\begin{array}{l}\text { Term used as a synonym for either the definition } \\
\text { given to FCA or as a synonym for TCA [28] }\end{array}$ & $\begin{array}{l}\text { (1) Conventional costs, (2) hidden costs, (3) } \\
\text { liability costs, (4) less tangible costs }\end{array}$ \\
\hline Life cycle accounting (LCA) & $\begin{array}{l}\text { The assignment or analysis of product-specific } \\
\text { costs within a life cycle framework [30] }\end{array}$ & $\begin{array}{l}\text { (1) Usual costs, (2) hidden costs, (3) liability } \\
\text { costs, (4) less tangible costs }\end{array}$ \\
\hline Life cycle cost assessment (LCCA) & $\begin{array}{l}\text { Systematic process for evaluating the life cycle } \\
\text { cost of a product or service by identifying en- } \\
\text { vironmental consequences and assigning mea- } \\
\text { sures of monetary value to those consequences } \\
\text { [5,31]. LCCA is a term that highlights the cost- } \\
\text { ing aspect of life cycle assessment (LCA) }{ }^{\mathrm{a}} \text { [28] }\end{array}$ & Add cost information to LCA \\
\hline Life cycle costing (LCC) (I) & $\begin{array}{l}\text { Summing up total costs of a product, pro- } \\
\text { cess or activity discounted over its lifetime } \\
{[24,27,28,30]}\end{array}$ & Varying \\
\hline Life cycle costing (LCC) (II) & $\begin{array}{l}\text { A technique which enables comparative cost as- } \\
\text { sessments to be made over a specified period of } \\
\text { time; taking into account all relevant economic } \\
\text { factors both in terms of initial costs and future } \\
\text { operational costs [ISO15686]. }\end{array}$ & Varying \\
\hline Full cost pricing (FCP) & Term used as a synonym for FCA or LCC [28] & See FCA and LCC \\
\hline Whole life costing (WLC) & $\begin{array}{l}\text { Synonym to TCA (I) or LCC [7]. More specif- } \\
\text { ically defined by Clift and Bourke [16] as "The } \\
\text { systematic consideration of all relevant costs } \\
\text { and revenues associated with the acquisition and } \\
\text { ownership of an asset" }\end{array}$ & (1) Initial costs and (2) operational costs \\
\hline
\end{tabular}

${ }^{\text {a }}$ Life cycle assessment (LCA) — an environmental management tool for evaluating the environmental impacts of products and services from cradle to grave in their life cycles [32].

${ }^{\mathrm{b}}$ This definition is not developed in an environmental context, it is defined in a building and construction assets standard [ISO15686].

These limitations entail that tools based on the neoclassical theoretical paradigm will always be beset with severe shortcomings concerning their use in handling environmental aspects. Furthermore, even though it is not an assumption for neoclassical economic theory, the use of discounting as a technique to handle the problem with time value of money is so routinely used as well as preferred by practitioners that it is well worth discussing [37-39]. This since

- using discount rates that rely on principles based on today's knowledge may result in future costs from decisions being given relative small weight in the LCC calculation.

These limitations in relation to environmental applications of LCC are discussed more extensively in the following section.

\subsection{Decision-making under uncertainty}

The environmental consequences of a decision often occur long after the decision was made, and not necessarily in the same location. Furthermore, environmental decisions have cumulative effects on ecological systems, which are difficult to detect [40]. Environmental decisions, being closely coupled with society's built-in uncertainties and risks, are genuinely uncertain since the way ecological systems as well as social systems change in the future need to be considered in the decisions [41]. Issues that are not considered as problems today may well be in the future, in the same way as today's environmental problems were not anticipated yesterday. Environmental decisions therefore are characterised by considerable uncertainty at all stages of the decision-making process, such as the problem definition, possible outcomes and probabilities of the outcomes [42].

Buildings, for example, are long-term investments associated with large environmental impacts over a long duration. To estimate environmental costs so far into the future may result in an LCC calculation that is faulty [43], i.e. the calculated LCC may have little resemblance to future real cost. Investment decisions for a building are affected by business, physical and institutional uncertainties [44]. Physical 
risks are often due to uncertainty as to a building's design or a material's functional characteristics and performance change during the building's lifetime. Such uncertainty may involve building material that through new scientific evidence has become unsuitable, as for example asbestos cement sheeting and CFC. Business uncertainty is connected to unpredictable fluctuations in the market and institutional uncertainties reflected in the effect of changing regulations on construction and real estate. Many political decisions can instantly change the "rules of the game". For example, building materials may become prohibited, as with the asbestos. It is also easy to envisage that materials and components that are difficult to recycle will be expensive to dispose of in the future both for technical reasons and due to increasing disposal taxes. In addition to political decisions, external market factors, institutional regulations and environmental changes may also lead to changing conditions. The modernity of a real-estate project is affected by customers' (tenants') increased awareness of environmental issues, which implies that buildings that are not continually adjusted to environmental norms or to presumptive regulations run the risk of becoming outdated rather quickly.

An analysis that relies on estimation and valuation of uncertain future incidents and outcomes is therefore problematic. There are numerous techniques available that attempt to decrease the uncertainty of future consequences, for example scenario forecasting, sensitivity analysis, probability analysis, decision trees and Monte Carlo simulation (see, for example, [19]). However, these techniques presuppose that decision makers are aware of the nature of the uncertainties that can be expected during the building's lifetime. A study of risk management [45] revealed that real-estate managers when conducting a sensitivity analysis of LCC only considered tangible aspects such as interest rate, rental degree and increase or decrease of rent. Furthermore, when estimating risk and uncertainty the property managers relied more often on their intuition and rules of thumb than on techniques, such as sensitivity analysis. This implies that easily accessible information and subjective values to a large extent influence the parameters considered in estimating risk and uncertainty, i.e. the result from the LCC are biased.

\subsection{Irreversible decisions}

Neoclassical theory assumes that alternative options are always available. However, the consequences of the decision to invest in building projects extend across a long period of time and many decisions lead to irreversible outcomes $[42,46]$. For example, in building a road it might be necessary to blast primary rocks. This encroachment on nature radically changes the topography, which is not restorable. So, when considering environmental aspects in decision-making, the basic assumption of the existence of available alternatives is not in accordance with current environmental reality. The depreciation of future consequences can often be of significant importance in an environmental context where the issue is to balance today's benefits with tomorrow's costs or vice versa. The large number of components in a building implies that several subsequent decisions must be made during the building's lifetime. The investment process therefore contains sequential decisions, meaning that earlier decisions will influence subsequent decisions. Since irreversible changes take place in ecological systems as well as in sequential decisions it is not possible to ignore irreversibility as the neoclassical economic theory does.

\subsection{The role of market mechanisms}

Property rights are the rights to use resources. In economic theory property has a wider meaning than in everyday language; it can refer to any good or resource [47]. Similarly, the environment is a resource and hence a property. For example, many people own land and they are able to take action when damage is done to assets they own, but they do not generally own the rivers or the air through which pollution travels. The lack of well-defined property rights, as in the case of air and water, makes it difficult for a market to exist, which problemises the concept of a market. The market system is central in neoclassical economic theory since it is a mechanism for generating an efficient allocation of resources. Environmental damage and pollution leads to market mechanisms ceasing to function because of ill-defined property rights of the natural environment (Coase theorem in $[47,48])$. In other words, neoclassical economic theory ignores items that are not given a market value. Consequently, due to LCCs basis in neoclassical economic theory LCC handles environmental aspects insufficiently.

\subsection{A monetary unit}

With the purpose of simplifying a complex reality, which is necessary out of a practical perspective, 'environmental' LCC aims at translating environmental problems into a one-dimensional monetary unit. However, a problem is that LCC in its attempt to translate environmental problems into a monetary unit may oversimplify reality. Neoclassical economic theory presupposes that all relevant aspects have a market value, i.e. a price. As mentioned in the previous section, there are items that are not possible to price. This leads to monetary calculations being incomplete with regard to environmentally related costs. Many economic theorists suggest different ways to put a price on environmental items for example through environmental taxes [47,48], but others argue that it is impossible to catch all relevant aspects of complex environmental problems into one monetary figure [49]. The monetarism of LCC consequently result in loss of important details which in turn limits the decision maker's possibility to obtain a comprehensive view of environmental problems. Söderbaum [49] argues that organizations that 
wish to comply with (and survive in) a complex reality must work with more holistic pictures and models than for example environmental 'LCC'. He suggests that organisations use additional methods to complement the monetary.

\subsection{Discounting of future costs}

If it does not matter when costs and benefits incur they can be added without consideration. However, if the timing of costs and benefit flows is important, the investment calculus needs to reflect this. A common technique is the use of discounting. The time value of money, expressed as a discount rate, depends on inflation, cost of capital, investment opportunities and personal consumption preferences $[10,37,38]$. If the discount rate is set to $0 \%$ this means that the timing does not matter; the higher the discount rate the more importance is given to the near-present.

The most common technique of making incoming and outgoing payments from different times comparable and thus possible to add is discounting future payments to a net present value (NPV). As shown in the box, using the interest rate $5 \%$ the future demolition cost of 1000 is calculated to an NPV of 90 (Example box).

An alternative given by for example Gray et al. [25] is to use an environmental hurdle rate technique. This technique is exemplified in the box by three hurdle rates: a 'green discount rate' for costs that do not contribute to negative impact on the environment, a 'yellow rate' for costs that have an uncertain contribution to negative impact on the environment, and a 'red rate' for costs that have a certain negative impacts on the environment. If 'red rates' are set to $0 \%$ in the LCC calculation, 'red' types of costs do not get discounted over time and therefore cause a more significant contribution to the total result when discounted. The use of 'red rates' is valid as long as future damage is assumed as negative as today's. For example, discharging toxic waste tomorrow should be as negative for the environment as discharging toxic waste is today. However, from an environmental point of view, the timing of the emissions depends on the state of the environment, which can improve or deteriorate with time. In addition waste management technology may also improve in the future. Because of such developments, it may be more viable that certain environmental costs are considered as green or yellow and thus discounted in the LCC calculation. This reasoning illustrates how complex and difficult it is to handle environmental costs and how over-simplification can misguide environmental decisions-making.

Another way of handling the time problem is to indicate which costs may be expected to increase more than other costs. A differential escalation rate can thus be used to indicate relative price changes [10]. In the box, costs for demolition are assumed to increase more than other costs. With a relative price change of $3 \%$ demolition costs are discounted at approximately $1.9 \%$ while all other costs are discounted

\section{EXAMPLE BOX}

Basic assumptions: For a building, the demolition cost is estimated to a value of 1000 . The lifetime of the building is estimated to 50 years and the discount rate is set to $5 \%$.

$$
\mathrm{LCC}=\sum_{t=0}^{T} P_{n}(1+i)^{-t},
$$

$n$ is number of estimated payments $P$ over time $t$ discounted with the interest rate $i$.

If the future payment for demolition is discounted with the interest rate the NPV is calculated to $\mathbf{9 0 .}$

Problem: However, due to an impending risk that demolition waste from the building causes a large environmental impact one can presume that demolition, due to, for example, new tax regulations, increased costs for disposing demolition waste or demand for new more expensive demolition methods, render in large future environmental costs.

\section{Hurdle rate principle:}

$$
\begin{aligned}
& \mathrm{LCC}= \sum_{t=0}^{T} P_{n, r}(1+r)^{-t}+\sum_{t=0}^{T} P_{n, y}(1+y)^{-t} \\
&+\sum_{t=0}^{T} P_{n, g}(1+g)^{-t} \\
& P=\text { payment }, r=\text { 'red' rate, } y=\text { 'yellow' rate, } \\
& g=\text { 'green' rate, } t=\text { time }
\end{aligned}
$$

If using the hurdle rate principle environmental cost due to demolition is discounted with a red discount rate, i.e. $r=0 \%$, in the LCC calculation. The result from the LCC calculation will then be that future demolition costs are calculated to an NPV of 1000, thus the same as if the real-estate building would have been demolished today.

\section{Price rate principle:}

$\mathrm{LCC}=\sum_{t=0}^{T}\left[P_{n} \frac{(1-e)^{t}}{(1+i)^{t}}\right]$

$P=$ payment, $i=$ interest rate, $e=$ escalation rate,

$t=$ time

Analogous, using the price rate principle, the relative price for demolition is likely to increase and can therefore be estimated to increase more than other types of costs in the calculation, say a relative price change of $3 \%$, i.e. $e=0.03$. The result from the LCC calculation then shows that future payment for demolition is calculated to an NPV of $\mathbf{3 8 0}$.

at the interest rate of $5 \%$. This entails that the future demolition cost of 1000 is calculated to an NPV of 380. 
The examples given in the box illustrates how important the setting of discount rate is for the LCC calculation. Neoclassical economic theory, as all economics, involves value judgements [46], i.e. the information from today's financial accounting systems reflects only what the economic leaders currently consider as important [23]. Consequently, by using discount rates that rely on principles based on today's knowledge of future costs may get a relatively small weight in the LCC calculation. The examples also reveal that when discounting in LCC calculation for a building a large number of estimations are required. Consequently, depending on the method, very different results are obtained.

\section{LCC-oriented tools in practice}

Even if not theoretically accurate, the results from an LCC calculation might provide at least an indication of which strategic decisions should be made. We have identified following issues as critical for the practical usability of LCC:

- The availability and reliability of environmental data.

- The perceived benefits of using LCC in investment decisions.

- An understanding of conceptual definitions and methods.

\subsection{Availability and reliability of environmental data}

Performing an LCC analysis is a data intensive process due to the complexity of the building process and the many components of a building. The final result is, therefore, dependent on the availability and reliability of the input data $[15,43]$. Table 2 exemplifies the range and diversity of the data needed to perform an LCC.

In the absence of real data, as the case is for planned buildings, forecasts can be based on past experiences. Data on costs [50-52], lifetimes [53] and energy use [54] of different building types and building components can be collected from estimation standards ${ }^{1}$ that provide data for an 'average' building. However, because of regional differences, the location of a building has a large effect on its final life cycle cost, for example, taxes and fees can vary and the location can also be more or less sensitive to environmental impacts, which makes the data received from standards not applicable for the situation in hand.

A more specific source of data is corporate historical data. A practicable way of tracing historical environmental costs could be through the corporate accounting system. Unfortunately, LCC suffers from the fact that a companies' accounting systems cannot handle environmental costs that have occurred elsewhere $[13,23]$. Furthermore, it is difficult to specify environmental costs from other costs in the corporate accounting system $[13,23]$. The insufficient recording

\footnotetext{
${ }^{1}$ The estimate standards exemplified with here are Swedish. Equivalent standards can probably be found in other countries as well.
}

Table 2

Examples of input data needed to perform an LCC for a building

\begin{tabular}{lll}
\hline Investment cost data & $\begin{array}{l}\text { Operation and } \\
\text { maintenance data }\end{array}$ & Project specific data \\
\hline - Building costs & - Administration & - Type of building \\
- Site costs & - Energy & $\begin{array}{l}\text { - Type of design } \\
\text { - Type of building } \\
\text { - Design fees }\end{array}$ \\
- Water & material \\
- Salvage value & - Waste water & - Location \\
- Demolition costs & - Material & - Lifetime periods \\
- Other & - Cleaning & - Other specific data \\
& - Maintenance & \\
& - Insurance costs & \\
& - Rates & \\
& - Othes & \\
\hline
\end{tabular}

of environmental costs in corporate accounting systems is identified as a major obstacle for the successful implementation of corporate environmental accounting tools [13]. This leads to a 'catch 22 ' situation, where corporate environmental accounting tools such as LCC cannot be implemented unless the environmental costs are measured.

Other obstacles to LCC implementation are poor quality of the data and a lack of industrial standards for describing the life cycle behaviour of buildings $[7,18,55,56]$. A way to clarify responsibility of execution of LCC calculations could be to formalise the use of LCC via contractual agreements [18]. This is suggested to avoid unclear responsibility since many actors and companies in the building process are involved only for a limited period of the buildings lifetime. This means that different actors feel different degrees of responsibility. Furthermore, data are sparsely recorded since "sharing" of data between different actors is not custom practice. This results in incomplete data being recorded in different accounting systems by different companies. In addition, studies show that environmental impacts of buildings are insufficiently identified $[55,57,58]$. A basic prerequisite for specifying environmental costs in corporate accounting systems is although that the environmental impacts are identified in the first place.

Given the lack of data and poor quality of existing data, it is difficult to produce LCC calculations supporting 'good' environmental decisions. Many assumptions and estimations must consequently be made, which implies that the result from the LCC calculation is naturally beset with a high degree of uncertainty. The uncertainty in forecasting future consequences causes decision makers to perceive LCC calculations as unreliable [18].

\subsection{Perceived benefits from using $L C C$}

In order to use LCC in investment decisions for buildings, the decision makers must perceive benefits from using it. The decision makers' limited capacity of processing 
large amounts of complex information results in lack of attention for new problems such as environmental problems [59]. Structuring the information flow by using unidimensional tools that integrate different decision dimensions (e.g. environment, economy, quality, time) may be a way of limiting the information flow and improving the decision-making [60]. Consequently, using LCC might bring clarity by translating a complicated reality to a, for the business world, familiar dimension, money. By translating the information to a monetary dimension it is possible that decision makers would include environmental concerns in the investment decision. However, even though LCC might translate environmental information into more familiar units, uncertainties pose special problems concerning cognitive and motivational influences on decisions, that is the decision maker's personal view of reality affects what parameters that are considered in the calculation $[61,62]$. Despite access to identical input data when making the decision, personal values and motives systematically affect for example which estimations and assumptions are included in the calculation. This results in different decision-makers arriving at different results and choices when using LCC-oriented tools.

An indirect benefit from performing an LCC for a building investment decision is that it may not be the actual monetary figures that provide the decision maker with insight, but instead the actual involvement in the process of carrying out an LCC $[3,59]$. Thus, collecting data, estimating future events, identifying environmental aspects to consider and so on might be the actual benefit, i.e. learning about the complexity and diversity of environmental costs from doing the LCC calculation. Learning capabilities is thus a rational benefit from non-rational behaviour and should not be neglected in the development of decision support tools. However, too structured tools may make decision-making mechanical [63]. By only operating the tool and/or only using the one-dimensional result in making their decisions the consequence may instead be that learning is restrained and that established values are conserved. Accordingly, results from analytically structured decision support tools may entail inappropriate reliance on the forecasts accuracy and consequently fail to identify relevant environmental features for the investment decision.

\subsection{Conceptual confusions}

Table 1 showed that there is much effort made on developing LCC-oriented environmental accounting tools among researchers. A closer look at Table 1 reveals a diversity of confusingly similar concepts of corporate environmental accounting tools. Some methods have different names, but similar principles in their algorithm (e.g. Life Cycle Costing and Full Cost Accounting); others have the same name, but different principles for the calculation (e.g. life cycle accounting and life cycle analysis) or the same name, but different principles for calculation as non-environmental versions of LCC (e.g. "environmental" life cycle costing and "traditional" life cycle costing). This diversity is likely to cause confusion among practitioners, which hinders them from adopting LCC-oriented environmental accounting tools. Evidence of such confusion has been found. Stenberg [64] reports that practitioners have problems in differentiating tools from each other, and they refer to, for example, life cycle assessment (LCA) when they actually mean an 'environmental' LCC.

Another conceptual confusion concerns which life cycle is used in the life cycle approach. It is important to acknowledge that different kinds of life cycles are considered in LCC. Furthermore, the life cycle represents a lifetime and is an estimated variable, not a constant. Four different lifetimes for buildings may be used in LCC: economic, technical, physical and utility life [10]. Economic lifetime is an estimate of the building's profitable time. Technical lifetime is the estimated number of years until the technology renders the building obsolete. Physical lifetime is the estimated period in which it is physically possible to use the building. Finally, the buildings utility life is the estimated time the building can satisfy established performance standards. So, depending on the choice of life cycle the time perspective differs, which affects the results from the LCC calculation when discounted to a net present value. In LCC, the economic life is the most common since the calculations most often have a cost minimization perspective [10]. Adding to the confusion there is another type of life cycle approach used in the environmental tool life cycle assessment. The life cycle in LCA does not represent a time as in LCC. The life cycle in LCA represents a physical chain of material flows related to a product, from resource extraction to waste management [65].

The diversity of different concepts of corporate environmental accounting tools, the multifaceted grouping of environmental costs and the inconsistency in estimating the life-cycle cause if not confusion, then at least ambiguous results. This not only makes the LCC-oriented tools difficult for the decision maker to use, it also undermines their confidence in the result from LCC [18]. The consequence from this distrust may be that they hesitate in using these tools.

\section{Summing up from a user perspective}

The discussion of LCC-oriented tools' has identified both pros and cons for the user, concerning their usefulness for environmental decision-making in building investments, see Table 3.

From a user perspective it seems to be a good idea to link environmental issues with financial consequences when implementing environmental issues in a corporate decision-making context. However, LCC-oriented tools are grounded in neoclassical economic theory, developed for pure financial analysis and the focus is therefore different from that of environmental analysis. From an environmental 
Table 3

The usefulness of LCC-oriented tools for environmental decision-making in building investments: Pros and cons

\begin{tabular}{|c|c|}
\hline PROS & CONS \\
\hline $\begin{array}{l}\text { LCC... } \\
\ldots \text { uses a familiar unit, money. } \\
\ldots \text { gives an indication on } \\
\text { which aspects to consider } \\
\ldots \text { limits the informa- } \\
\text { tion flow by simplifying } \\
\text { multi-attributed alternatives. } \\
\ldots \text { may entail learning by par- } \\
\text { ticipating in the calculation } \\
\text { process } \\
\ldots \text { has a life cycle perspective }\end{array}$ & $\begin{array}{l}\ldots \text { underrates future environmental } \\
\text { costs } \\
\ldots \text { suffers from poor availability and } \\
\text { reliability of data } \\
\ldots \text { relies on many estimated variables } \\
\text { due to the complexity of the building } \\
\text { and building process } \\
\ldots \text { results are biased towards the } \\
\text { decision maker's personal values } \\
\ldots \text { may restrain learning if too } \\
\text { mechanically used } \\
\ldots \text { is beset with conceptual confusion } \\
\text { due to many similar LCC-oriented } \\
\text { tools and inconsistent life cycles. }\end{array}$ \\
\hline
\end{tabular}

perspective the theory is incapable of incorporating uncertainty, irreversible decisions, items with no owner as well as future costs. The consequence is that environmental dimensions are insufficiently accounted for LCC fails as an appropriate tool for environmental decision-making.

However, LCC-oriented tools may still be useful in practice if the decision maker is aware of the tool's inherent limitations. Furthermore, the decision maker's participation in the LCC calculation process may contribute to learning effects, which in turn may increase his/her knowledge concerning environmental issues.

Still, LCC is afflicted with serious practical problems, foremost concerning poor availability and reliability of input data. Lack of data implies that the investment decision is carried out under uncertainty which means that the decision-maker must make many estimates. When decision makers are faced with uncertainty they generally make estimations that are biased towards their own values and motives rather than being objective to the problem in hand [11]. This renders the reliability of LCC as an information provider for environmentally responsible decisions questionable.

\section{Three research approaches to future development of environmental decision support tools}

Making environmental decisions is complex. There are several tools available today that intend to structure and simplify this complexity and support the decision maker in making environmental considerations in a building investment situation. However, as argued here several of these are insufficient for the problems environmental decision-making is afflicted with. To solve some of these problems future efforts in the development of decision support tools must be made. Three areas of research are identified:

(1) Further development of tools that integrate environmental and micro-economic dimensions. This approach follows the device 'little is better than nothing' and is foremost supported by the decision makers' familiarity with economic units. It is advocated by, for example, Epstein [13]. However, in order to raise the decision makers' trust in the results from LCC, the availability and reliability of data must be secured. Furthermore, to avoid ambiguity a joint platform of definitions and groupings must be developed.

(2) Extend the system boundaries by complementing LCC-oriented tools with tools that focus on physical measures, for example LCC and life cycle assessment. This approach is suggested by several researchers (for example $[7,8,49]$ ) and recognises the environmental aspects more extensively. However, if too mechanically used by the decision maker this approach has shortcomings in recognising the decision maker's cognitive skills.

(3) Improve the understanding of environmentally related decision-making and use of tools. This approach acknowledges that individuals in making decisions use cognitive skills which are influenced by both personal values and perceived benefits. Recognising the decision-maker's behaviour, an extended approach and a way forward is to develop and use decision strategies that also consider cognitive aspects.

The development of corporate decision support tools for the building industry that consider environmental dimensions in ways that follow approaches 1 and 2 has been ongoing for at least a decade. Success in making it attractive and 'understandable' for a wider adoption of LCC in the building industry seems to be limited though [17-19]. For example lack of data, lack of contractual agreements, too laborious analyses, and lack of standardisations are mentioned as obstacles. A life cycle perspective is good since it extend the system boundaries and incorporates some costs that incur in the future. By, in addition to LCC, using an environmental assessment tool, such as LCA, in the investment decision both long-termed costs as well as environmental impacts are considered. However, an improved bad concept is still a bad concept. In addition to LCCs imperfect theoretical base other aspects must be recognised of why these tools are not considered as useful by the practitioners themselves. Approaches 1 and 2 often build on the notion that decision makers are rational and use decision support tools to rationally evaluate options (alternatives) in order to 


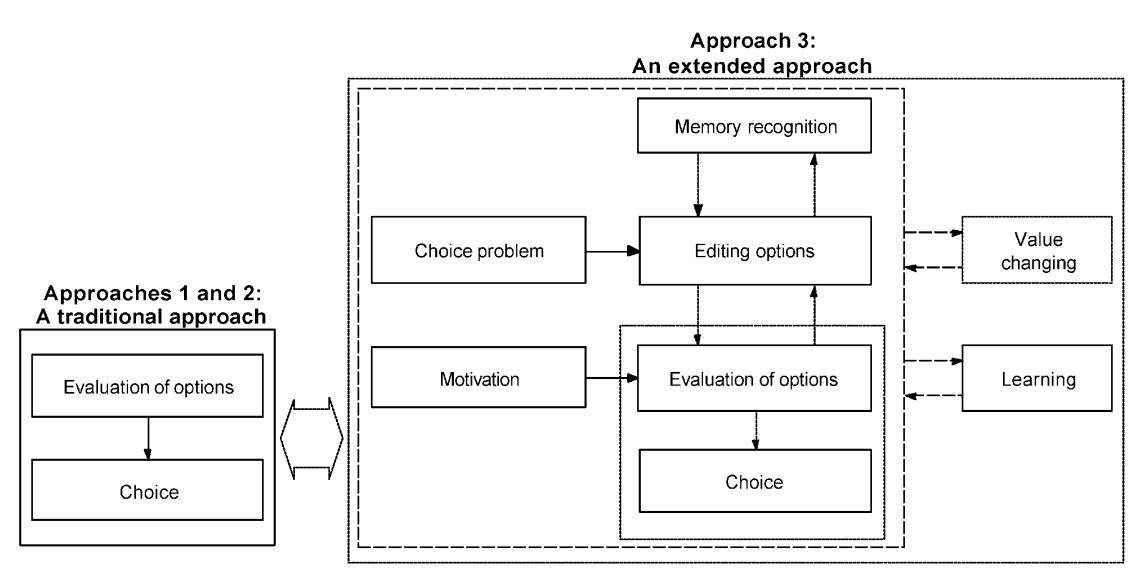

Fig. 1. Extending the investment decision context (modified from Gärling et al. [66]).

make a choice. Furthermore, approaches 1 and 2 provide the decision makers with tools based on the principle that systematic gathering and analysing of information is the best route to an optimal decision.

A change towards more environmentally responsible behaviour in the building industry requires less focus on tool production and more on understanding the decision making process and the role tools play in this process. As a complement to developing tools, according to approaches 1 and 2, it is necessary to develop a wider understanding of how decision making takes place. As illustrated in Fig. 1, approach 3 considers the decision maker's situation and behaviour and thus recognises the importance of other decision processing aspects in addition to making a rational choice among alternatives. The development of environmental decision support tools that goes beyond the rational choice has long been a neglected area of study $[40,46]$. Such an extended perspective upon the decision-making context gives rise to an area of research where researchers with different background should cooperate. The outcome from future research may be that tools that involve people in the decision process, such as brainstorming about the issue and about decision options, are developed in addition to structured analytical tools.

\section{Acknowledgements}

We would like to thank Dr. Christine Räisänen, Chalmers University of Technology, Sweden and an anonymous referee for valuable comments on this article. This research was financially supported by MISTRA.

\section{References}

[1] Hamner B, Stinson CH. Managerial accounting and environmental compliance costs. Journal of Cost Management 1995;9(2):4-10.

[2] Kite D. Capital budgeting: integrating environmental impact. Journal of Cost Management 1995;9(2):11-4.
[3] Zaring O. Capital budgeting for the unexpected. Scandinavian Journal of Management 1996;12(3):233-41.

[4] Cohan D, Gess D. Integrated life-cycle management. New York: IEEE; 1994. p. 149-54.

[5] Bennett M, James P. Environment-related management accounting: current practice and future trends. Greener Management International 1997;97(17):32-52.

[6] Abraham DM, Dickinson RJ. Disposal costs for environmentally regulated facilities: LCC approach. Journal of Construction Engineering and Management 1998;124(2):146-54.

[7] Sterner E. Green procurement of buildings: estimation of life-cycle cost and environmental impact. Ph.D. dissertation thesis, Department of Mining Engineering, Luleå University of Technology, 2002.

[8] Aye L, Bamford N, Charters B, Robinson J. Environmentally sustainable development: a life-cycle costing approach for a commercial office building in Melbourne, Australia. Construction Management and Economics 2000;18:927-34.

[9] Bogenstätter U. Prediction and optimisation of life-cycle costs in early design. Building Research and Information 2000;28(5/6): 376-86.

[10] Kirk SJ, Dell'Isola AJ. Life cycle costing for design professionals. New York: McGraw-Hill, Inc.; 1995.

[11] Hogarth R. Judgement and choice, (2nd ed.). Chicago: Wiley; 1994.

[12] Wade-Benzoni KA, Tenbunzel AE, Bazerman MH. Egocentric interpretations of fairness in asymmetric, environmental social dilemmas: explaining harvesting behavior and the role of communication. Organizational Behavior and Human Decision Processes 1996;67(2):111-26.

[13] Epstein MJ. Measuring corporate environmental performance. Chicago: Irwin Professional Publishing; 1996.

[14] Bennett J, Norman G (editors.) Construction Management and Economics 1987; 5(Special issue).

[15] Sterner E. Life-cycle costing and its use in the Swedish building sector. Building Research and Information 2000;28(5/6):387-93.

[16] Clift M, Bourke K. Study on whole life costing. DETR Report No. CR 366/98, 1999.

[17] Larsson N, Clark J. Incremental costs within the design process for energy efficient buildings. Building Research and Information 2000;28(5/6):411-6.

[18] Cole RJ, Sterner E. Reconciling theory and practice of life-cycle costing. Building Research and Information 2000;28(5/6):368-75.

[19] Flanagan R, Kendell A, Norman G, Robinson GD. Life cycle costing and risk management. Construction Management and Economics 1987;5(special issue):53-71. 
[20] Norman G. Life cycle costing. Property Management 1990;8(4): $344-56$.

[21] Atkinson G. Measuring corporate sustainability. Journal of Environmental Planning and Management 2000;43(2):235-58.

[22] Bartlett E, Howard N. Informing the decision makers on the cost and value of green building. Building Research and Information 2000;28(5/6):315-24.

[23] Schaltegger S. Corporate environmental accounting. Chichester: Wiley; 1996.

[24] Spitzer M, Elwood H. An introduction to environmental accounting as a business management tool: key concepts and terms. Washington, DC: EPA; 1995.

[25] Gray RH, Bebbington J, Walters D. Accounting for the environment. London: Paul Chapman; 1993.

[26] van der Veen M. Environmental management accounting. In: Kolk A, editor. Economics of environmental management. Harlow, UK: Pearson Education Ltd.; 2000. p. 155-75.

[27] Henn CL. The new economics of life cycle thinking. New York: IEEE; 1993.

[28] Spitzer M, Pojasek R, Robertaccio F, Nelson J. Accounting and capital budgeting for pollution prevention. United States Environmental Protection Agency. In: The Engineering Foundation Conference 1993. January 24-29. San Diego, CA.

[29] White A, Becker M. Total cost assessment: catalyzing corporate self interest in pollution prevention. New Solutions 1992; 34ff.

[30] EPA. Life cycle design guidance manual: environmental requirements and product system. EPA-600-R-92-226, 1993. p. 122-9.

[31] Warren JL, Weitz KA. Development of an integrated life-cycle cost assessment model. New York: IEEE; 1994. p. 155-63.

[32] Baumann H, Cowell SJ. An evaluative framework for conceptual and analytical approaches used in environmental management. Greener Management International 1999;26:109-22.

[33] Wycherley I. Environmental managers and accounting. Journal of Applied Management Studies 1997;6(2):169-85.

[34] Kreuze JG, Newell E. ABC and life cycle costing for environmental expenditures. Management Accounting 1994; 38-42.

[35] Cyert RM, March JG. A Behavioral theory of the firm. Englewood Cliffs, NJ: Prentice-Hall; 1963.

[36] Caroll JS, Johnson EJ. Decision research—a field guide. Newbury Park, CA: SAGE Publications Inc.; 1990.

[37] Pike R, Dobbins R. Investment decisions and financial strategy. Hemel Hempstead, UK: Philip Allan; 1986.

[38] Perkins F. Practical cost benefit analysis. Basic concepts and applications. South Melbourne, Australia: MacMillan; 1994.

[39] Zaring O. Capital budgeting and the environment. Ph.D. dissertation thesis, School of Economics and Commercial Law. Göteborg: university of Göteborg, Sweden, 1999.

[40] English MR. Environmental decision making by organizations: choosing the right tool. In: Sexton K, Marcus AA, Easter W, Abrahamson DE, Goodman JL, editors. Better environmental decisions. Washington, DC: Island Press; 1998. p. 57-75.

[41] Wolff R. Beyond environmental management-perspectives on environmental and management research. Business Strategy and the Environment 1998;7:297-308.

[42] Gough JD, Ward JC. Environmental decision-making and lake management. Journal of Environmental Management 1996;48:1-5.

[43] Ashworth A. Estimating the life expectancies of building components in life-cycle costing calculations. Structural Survey 1996;14(2):4-8.

[44] Bejrum H, Hanson R, Johnson B. Det levande hustets ekonomi-livscykelekonomiska perspektiv på drift och förnyelse. Anslagsrapport A3:1996, Stockholm: Byggforskningsrädet, 1996.

[45] Strömgren C, Hantering av osäkerhet och risk vid fastighetsekonomiska beslut. Licentiate thesis, Göteborg, Sweden: Department of Building Economics and Construction Management, Chalmers University of Technology, 1995.
[46] English MR, Dale VH. Next steps for tools to aid environmental decision making. In: Dale VH, English MR, editors. Tools to aid environmental decision making. New York: Springer; 1999. p. $317-28$.

[47] Pearce D, Turner RK. Economics of natural resources and the environment. Hemel Hempstead, UK: Harvester Wheatsheaf; 1990.

[48] Hanley N, Shogren JF, White B. Environmental economics: in theory and practice. London: MacMillan Press Ltd.; 1997.

[49] Söderbaum, P. Människor och miljö i bilder av företag. In: Dobers, P, editor. Miljömanagement — guld och gröna skogar. Stockholm, Sweden: Nerenius \& Santérus Förlag; 1998.

[50] Repab. Årskostnader 2000: nyckeltal för kostnader och förbrukningar. Mölndal, Sweden: Repab Program AB, 2000.

[51] Repab Underhållskostnader. Mölndal, Sweden: Repab Program AB; 2000.

[52] Svenska kommunförbundet. Kalkylhandbok för fastighetsföretaget. Stockholm: Svenska kommunförbundet; 1996.

[53] Juhlin L. Brukstider och livslängder för byggnader och byggnadsdelar. Stockholm: Statens Råd för Byggnadsforskning; 1979.

[54] Adalberth, K. Energy use and environmental impact of new residential buildings. Dissertation thesis, Department of Building Physics, Lund Institute of Technology, Lund, Sweden, 2000.

[55] Brunklaus B, Thuvander L. Do Swedish property management companies have necessary conditions for environmental management? An interview study on environmental data availability. In: Proceedings of the 10th International Conference of the Greening of Industry Network, June 23-26, Göteborg, Sweden, 2002.

[56] Nicolini D, Tomkins C, Holti R, Oldman A, Smalley M. Can target costing and whole life costing be applied in the construction industry?: evidence from two case studies. British Journal of Management 2000;11:303-24.

[57] Borg M. Environmental assessment of materials, components and buildings: building specific considerations, open-loop recycling, variations in assessment results and the usage phase of buildings. Dissertation thesis, TRITA-BYMA 2001:4. Royal Institute of Technology, Department of Building Sciences, Stockholm, Sweden, 2001.

[58] Gluch P. Costs of environmental errors (CEE): a managerial environmental accounting tool or a symptom of managerial frustration? Greener Management International 2000;31:87-100.

[59] Vlek C. Essential psychology for environmental policy making. International Journal of Psychology 2000;35(2):153-67.

[60] Bazerman M. Judgement in managerial decisions, (4th ed.). New York: Wiley; 1998.

[61] Segelod E. Capital investment appraisal-towards a contingency theory. Lund: Studentlitteratur; 1991.

[62] Ajzen I, Fishbein M. Attitude-behaviour relations: a theoretical analysis and review of empirical research. Psychological Bulletin 1977;84:888-918.

[63] Glover SM, Prawitt DF, Spilker BC. The influence of decision aids on user behavior: implications for knowledge acquisition and inappropriate reliance. Organizational Behavior and Human Decision Processes 1997;72(2):232-55.

[64] Stenberg A.-C. Fallbeskrivning: Markanvisningstävling för bostäder med kretsloppstänkande, fastigheten Kikaren 8, Karlstad. Report. Göteborg, Sweden: Department of Building Economics and Management, Chalmers University of Technology, 2000.

[65] SS-EN ISO 14040, 1997.

[66] Gärling T, Karlsson N, Romanus J, Selart M. Influences of the past on choices of the future. In: Ranyard R, Crozier R, Senson O, editors. Decision making: cognitive models and explanations. London: Routledge; 1997. p. 167-88. 